\title{
USED THE BUSINESS MODEL OF CANVAS (BMC) TO CREATE ALTERNATIVE STRATEGIES IN BUSINESS DEVELOPMENT OF THE MICRO SMALL MEDIUM ENTERPRISES
}

\author{
Purwantoro \\ Rina Ari Rohmah \\ University of Pasir Pengaraian
}

\begin{abstract}
Micro Small medium enterprises (UMKM) in each state specifically in the ASEAN region faced with the situation of global competition. A very tight competition is forcing businessmen to Become the best. One of the ways that it can be Reached by the trade to be Able to be the best business strategy is Appropriate, effective and efficient. This research aims to find out how the application business model canvas in creating alternative business strategies for the development of UMKM. The second objective is to know the proper strategic alternatives for the development of UMKM. The methods used in this research is descriptive qualitative approach with the use of informants as respondents research. The source of data used is the business owners as much as 16 UMKM who open businesses in the downtown area of Pasir Pengaraian. Data collection techniques directly using interview techniques, observation and documentation. This research uses a template business model canvas to map strategy for the effort and combined with the SWOT analysis. Based on Data Obtained from the results of research, that the description of the business model approach of UMKM using Business Model Canvas outline can be used as Recommendations for business strategy, the business model of the which is currently already underway is Able to meet the Nine elements of the blocks on the template business model canvas. The findings of this research are that not all the UMKM business strategy and have just run a business without the vision of enterprise development. Based on the results of the SWOT analysis can be found that new alternative Efforts by optimizing internal strength in revenue streams on each of UMKM and conduct of elections to the right customer segments. Suggestions that may the researcher pointed out every UMKM should be more online to have the vision to grow and continue to innovate against products goods or services, increase of customer segmentation and the make use of business model canvas approach in making the strategy of the business.
\end{abstract}

Keyword: Business Model Canvas, UMKM, Business Strategy, Rokan Hulu

\section{INTRODUCTION}

Small and Medium Enterprises (UMKM) in every state, especially in the Asean region faced with fierce global competition. Fierce competition is forcing companies to be the best of the best to be able to survive in the era of globalization. By 2016 the number of entrepreneurs Indonesia has around $3.1 \%$ of the total population, meaning that only $2 \%$ of the total population of Indonesia. When compared with the countries of Southeast Asia and other developed countries the number is still far behind. Entrepreneurial Ratio of 3.1 percent is still lower compared to other countries such as Malaysia 5\%, China 10\%, Singapore $7 \%$, Japan $11 \%$ and the US $12 \%$. Rokan Hulu is an area that has good economic potential in line with the growth and development of all sectors but not in line with 
the development of UMKM in Rokan Hulu experiencing stagnant growth, where there are currently 36044 UMKM business operators (kumkm.riau.go.id) and ranks only eighth position of 12 districts in the province of Riau. Seeing these symptoms so it will need a breakthrough to improve the entrepreneurial passion, which is now Rokan Hulu become a new tourist destination area.

There are some policies that have been implemented by the Government especially Riau Province which was instrumental in the development and growth of UMKM in the province of Riau in general include:

1. Conducting business coaching programs, and ability in mastering the technology for entrepreneurs and industrial relocation.

2. Through the Research and Development Agency (BPP) Riau has been preparing young people to be fostered, in cooperation with the working unit at the district / city, the Department of Labor, Department of Tourism, Department of Industry and Trade and other agencies concerned.

3. PNM as a state provide financial services or capital, as well as management services (capacity building) so that it can sustain the quality of financing services.

4. Respect for creative people through Sagang Award each year.

Problems in the field contained in Rokan Hulu is due to several factors that lead to decrease in the number of UMKM in Rokan Hulu, among others:

1. UMKM are not able to perform the efficiency of its operations, so it ceases to operate,

2. Many other regions of UMKM to move his shop to look for opportunities

3. Most UMKM are not able to withstand the competition in the market, so it has implications for the declining performance achieved every company

Efforts to resolve the problems faced by UMKM located in the district especially in
Rokan Hulu need for business analysis using the Business Model Canvas (BMC) for this analysis was able to explain thoroughly both in terms of marketing, human resources, finance, up to a value or products offered. So that employers can determine the direction of move for the company and know the existing competitive advantage in the business is being run. a business model is needed to describe the rationale of how an organization creates, delivers, and captures value. This means that we can understand that a business organization that wants to be successful and able to expand its business must create, deliver and capture value associated with the activity of the business organization, business organization is no exception with UMKM. To advance this effort, UMKM need to understand how to actually create the best values to consumers who want dijangkaunya, so that their business activities earn the trust of customers for providing the best values. Implementation bussines model of canvas have been made by several previous studies that according to Osterwalder and pigneur (2012: 14) says that the business model can be described very well through nine basic building blocks that shows how to think on how companies make money. Nine of the building blocks is the Business Model Canvas arranged in an arrangement that is a unity. Business Model Canvas consists of nine building blocks, namely: Customer Segments (Customer Segment), Value propositions (Proportion of Value), Channels (Channels), Customer Relationship (Customer Relations), Revenue Streams (Flow income), Key Resources (Key Resources) Key Activities (Key Activities), Key Partnership (Partnership Main), Cost Structure (fee Structure). The parts are then mapped into two sides of the right side (creative) and left (logical). Business activities conducted both large enterprises and small businesses indirectly has implemented a business model canvas in running its business operations, although in practice only use a few blocks of nine building blocks. Value propositions 
(Proportion of Value), Channels (Channels), Customer Relationship (Customer Relations), Revenue Streams (Flow income), Key Resources (Key Resources), Key Activities (Activities Key), Key Partnership (Partnership Main), Cost Structure (fee Structure). The parts are then mapped into two sides of the right side (creative) and left (logical). Business activities conducted both large enterprises and small businesses indirectly has implemented a business model canvas in running its business operations, although in practice only use a few blocks of nine building blocks. Value propositions (Proportion of Value), Channels (Channels), Customer Relationship (Customer Relations), Revenue Streams (Flow income), Key Resources (Key Resources), Key Activities (Activities Key), Key Partnership (Partnership Main), Cost Structure (fee Structure). The parts are then mapped into two sides of the right side (creative) and left (logical). Business activities conducted both large enterprises and small businesses indirectly has implemented a business model canvas in running its business operations, although in practice only use a few blocks of nine building blocks. Cost Structure (Fee Structure). The parts are then mapped into two sides of the right side (creative) and left (logical). Business activities conducted both large enterprises and small businesses indirectly has implemented a business model canvas in running its business operations, although in practice only use a few blocks of nine building blocks. Cost Structure (Fee Structure). The parts are then mapped into two sides of the right side (creative) and left (logical). Business activities conducted both large enterprises and small businesses indirectly has implemented a business model canvas in running its business operations, although in practice only use a few blocks of nine building blocks.

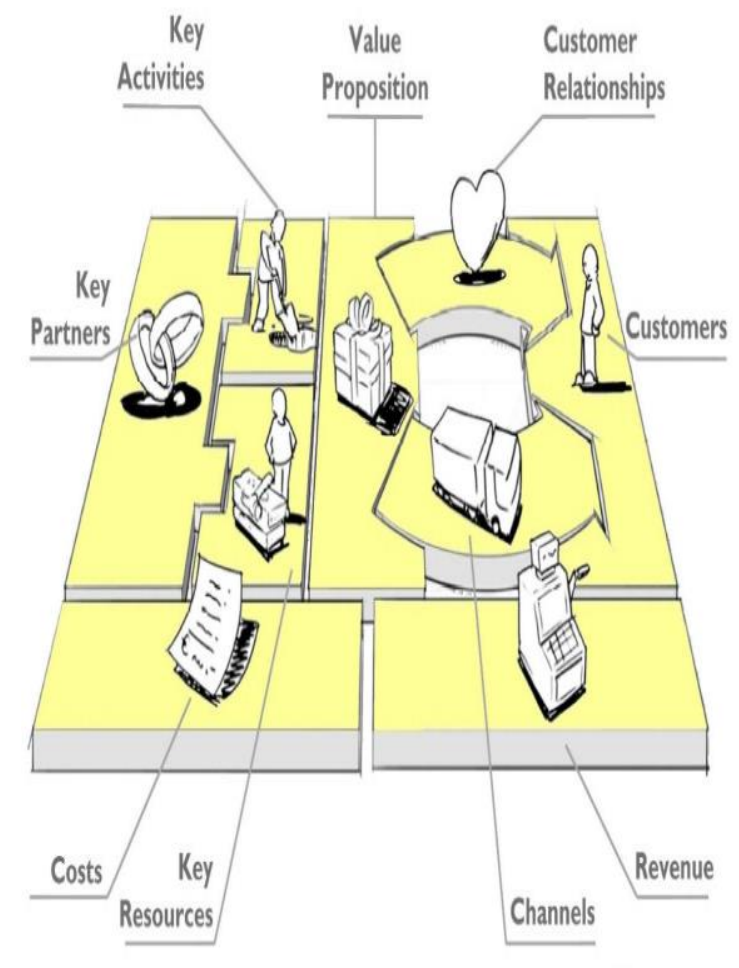

Source: Osterwalder and Yves Pigneur (2012: 19)

Other studies also menjelekaskan that the Business Model Canvas can be a simple tool to generate alternative company strategies that led to the financial feasibility (Dewobroto, 2013). The same thing conveyed by (Tjitradi, 2015) that in his research stating that the Business Model Canvas is a business model that can be used as the evaluation and design of a new business model that is better and more modern for the ongoing effort in the future. The same thinking is also conveyed by (Boedianto and Harjati, 2015) stated business model canvas can be used as an approach for creating business development strategies. Good business models are always concerned about customer value, customer relations, customer segments, and always put forward the application of more modern technology to create customer satisfaction (Stefan and Richard, 2014). Additionally (Princess, 2015) that the use of BMC approach can provide greater business opportunities for business 
development with entrepreneurs SWOT analysis can determine the threat. This study aims to find alternatives to new business strategy bussines canvas and apply models to map existing UMKM in Rokan Hulu.

\section{FRAMEWORK HYPOTHESES}

\section{THEORY}

AND

This study uses the elements of the business model canvas to identify and find the elements that occur in UMKM in Rokan Hulu. After identifying elements of BMC, researchers analyzed SWOT of UMKM that aim to create a map of the internal and external strength of the business. SWOT analysis of the reasons used in this study is because, according to Kurtz (2008.45) SWOT analysis is a strategic planning tool that is essential to help planners to compare the strengths and weaknesses internal to the organization with the opportunity and the threat of external, while Pearce and Robinson (2007.134) SWOT analysis is necessary because a SWOT analysis to match the fit between internal resources and external situation of the company. Matching the good will maximize the power and opportunity for the company and minimize weaknesses and threats. This simple assumption has strong implications for the design of a successful strategy. Added again by Robert W.Duncan (2007, 142) analyzing the internal and external environment is important in the process of strategic planning. Internal environmental factors in the firm usually can be classified as Strength (S) or Weakness (W) and the external environment can be classified as Opportunities $(\mathrm{O})$ or Threat $(\mathrm{T})$. According to Thompson (2008.97) SWOT analysis is simple, but it is a very powerful tool to increase the capability and know the inefficiency of resources, and opportunities of the market and external threats to the future so much better. While the reasons to use Business Model Canvas element analysis (BMC) in this study was to determine the extent to which the strategy has been used by
UMKM in Rokan Hulu. So far the use of Business Model Canvas is only used in the course of business, the research initiative using the business model canvas to map out strategies that combine MSME SWOT analsisi circuitry. This study has the following framework: the research initiative using the business model canvas to map out strategies that combine MSME SWOT analsisi circuitry. This study has the following framework: the research initiative using the business model canvas to map out strategies that combine MSME SWOT analsisi circuitry. This study has the following framework:

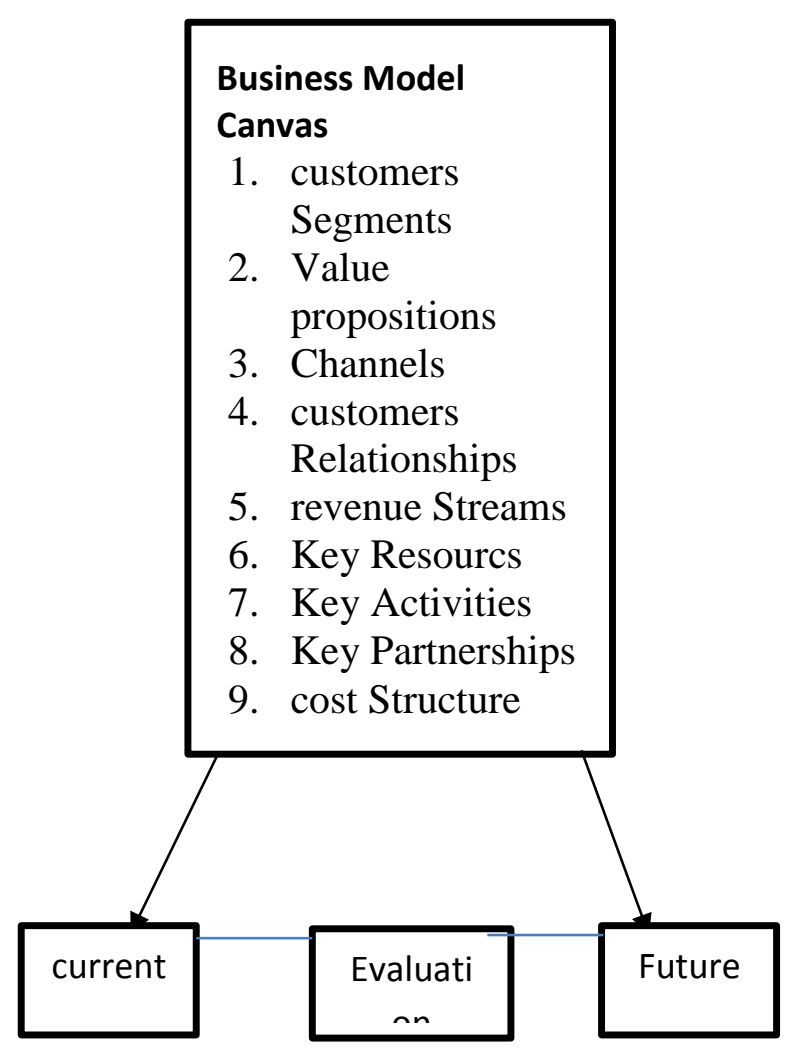

Source: Osterwalder and pigneur (2009)

\section{RESEARCH METHODS \\ Research sites}

Reasons research locations in consideration of the theory according to Moleong (2014: 51) determines the best way to be reached by road considering the substantive theory and exploring the field and look for conformity with the reality on the ground. While the limitations of geography and practical 
considerations such as: time, cost, effort should also be taken into consideration in determining the location of the study. Location of research undertaken in this study determined intentionally (purposive), the study was conducted in Rokan Hulu considering that Rokan Hulu regency development is most excellent development but the development of UMKM which included slow so that it fits in this study.

\section{Research focus}

The focus of this research is focused on the application of the business model canvas in the creation of the business strategy for the development of micro small and medium .. The determination of the focus of research is more focused on the novelty level of information to be obtained from a social situation (field) (Sugiyono, 2013).

\section{Research subject}

The subjects were informants. In this study, the informant is divided into two, namely: 1 . The key informants (key informant), 2. informant supporters. The key informants in this study is the owner of Micro, Small and Medium Enterprises (MUMKM). While supporting informants are the employees, stakeholders and customers. Determination of informants in this study snowball sampling. The reason researchers used snowball sampling technique is where a particular situation, the number of research subjects involved be increased, because the subject or research informants predetermined not provide in-depth information or in certain situations do not allow researchers to gain access to the source, location or subject who want to study. The informant in the study have the following criteria:

1. The owners of UMKM

2. UMKM employees who have worked at least one year.

3. Consumers who have purchased the products of UMKM regularly or continue.
4. stakeholder relating to UMKM such as suppliers, partners and others.

5. Aged between 15-40 years of healthy physical and spiritual.

6. Able to communicate

7. Willing to become informants.

\section{Data collection technique}

The data collection technique is the most important step in the study, because the main goal of the research is to obtain data. This study uses three methods of data collection are:
1. Interview
2. Observation
3. Documentation

\section{Data analysis technique}

To use a template digging the Business Model Canvas with three stages of data processing, as in the following picture:

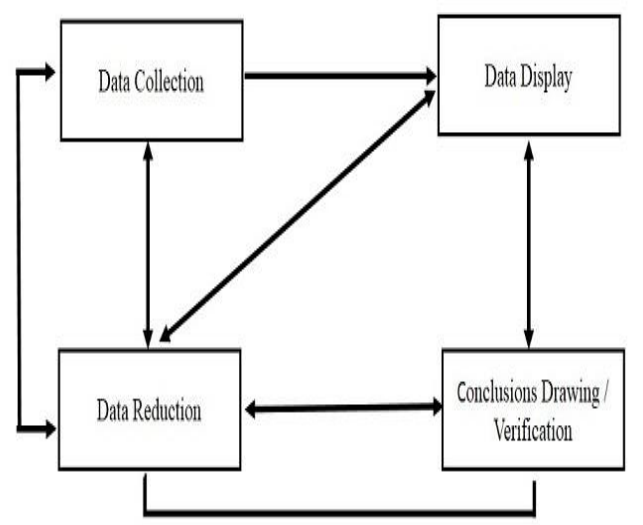

1. Data Reduction (Data Reduction) Data reduction means summarizing, choose the basic things, focus on the things that are important, look for themes and patterns and remove unnecessary. The data obtained from the field quite a lot, so it's worth noting thorough and detailed. The longer the researcher from the field, then the 
amount of data will be more and more complex and complicated. For that we need to make data analysis through data reduction. Which aims to select, summarize and focus on the important data that we want.

2. Data Display (Data Presentation)

Once the data is reduced, then the next step is to display the data. The aim is to facilitate the display of data and understand what is happening, and to plan further work based on what was understood. Besides displaying the data also to facilitate researchers in seeing the overall picture or a particular part of the study. In this study the presentation of the data will be displayed using the Business Model Canvas template with Canvanizer 2.0

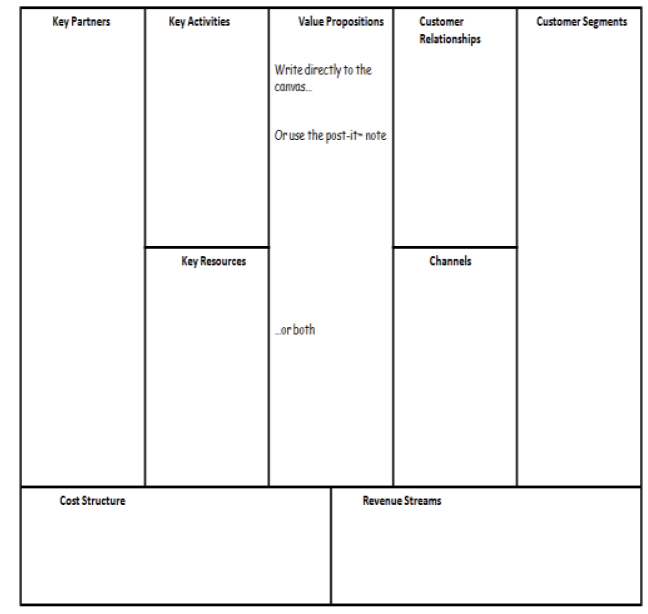

3. Conclusion Drawing / Verification (Withdrawal Conclusion)

Inferences conducted to verify on an ongoing basis throughout the study process, ie during the data collection process. In a study conducted, the conclusion is done by taking the essence of a series of categories of research based on interviews, observation, and documentation. Which the researchers wanted to know the relationship patterns, themes, and issues that often arise, hypotheses and so forth in the conclusions.

\section{RESEARCH RESULT}

Research will discuss the results of interviews with UMKM in Rokan Hulu is about the description of the 9 elements Business Model Canvas (BMC).

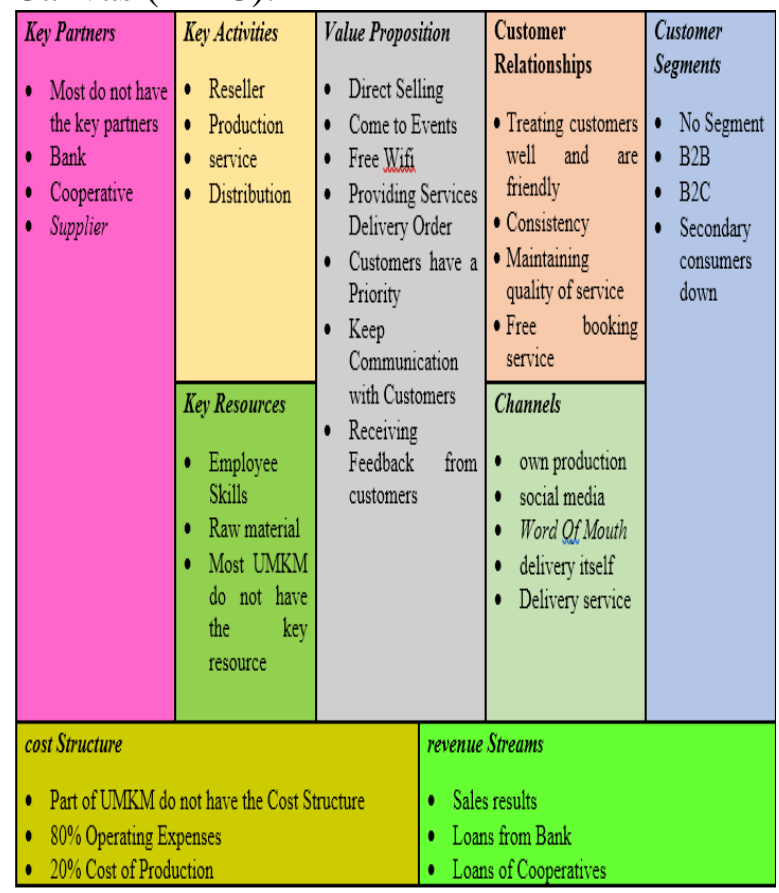

Source: Primary Data Processing, 2017

Key Partnerships

Key partnerships the parties having joint ventures with businesses. Owners of businesses in Rokan Hulu has the potential partners such as suppliers and customers that can assist the owner in achieving its goals. In addition, the partners shared by most UMKM today has the potential to have a long-term relationship and have the ability to float the business in terms of funding.

\section{Key Activities}

Key Activitiesin the business world give a good impact in developing the business. Business owners take such action to be operationally successful. Some UMKM in Rokan Hulu activities of production, distribution to customers and resell the products to consumers. 


\section{Value propositions}

Value propositionsie the value to be given by a business to the customer segmentsnya. Perspectives of value to UMKM in Rokan Hulu is found not only profit oriented where only concerned with profit, but also the quality, communication, service and a good relationship with the customer. Judging from the elements contained in the value propositions, namely: direct selling, visit events, menyedia free wifi, providing services delivery order, have a customer priority, menjada communication with customers, receive feedback from customers. means UMKM in upstream rokan been trying to maintain their efforts still exist.

\section{Customer Relationships}

Customer relationshipsis a kind of relationship to be built by businessman with each specific customer segments. UMKM contained in Rokan Hulu strive to maintain good relations with customers. It can be said that the category of customer relationships is also applied in the UMKM in Rokan Hulu is working totreat customers well and friendly, trying to maintain the consistency of effort in production and product quality, maintain the quality of service to consumers and tried to give booking service speed

\section{Customer Segments}

Customer segmentsie segments target customers of a business. The target market on UMKM in Rokan Hulu is more to the consumer segment in the lower middle income. And there is also some UMKM do not have segments, which means it has a very broad pasr segment. All UMKM in Rokan Hulu engaged in B2B and B2C business.

\section{Channel}

Channelare all ways to reach / communicate with customers. UMKM in Rokan Hulu reach the direct customer (own channels) and indirect (partner channels). Business process undertaken by UMKM is utilizing its own production capabilities and build your channels to utilize social media and word of mouth. As well as some UMKM have built a channel by working with some of the existing shipping services in Rokan Hulu.

\section{Key Resources}

Key resourcesan enterprise resource needed by the company to create and offer a value proposition, gain market share, maintaining relationships with customers and earn revenue segments. Key resources on UMKM in Rokan Hulu can be viewed from two elements: the physical (raw materials) and human (employees), while the majority of UMKM do not have the clarity of key resources.

\section{Cost Structure}

cost structureie all costs incurred by the company / business. Basically UMKM in Rokan Hulu has sought to strike a balance between fixed and operational costs which include the cost of equipment, cost of equipment, the cost of gasoline, the cost of employee salaries, the cost of renting the shop and shipping. Characteristics of the cost structure of UMKM in Rokan Hulu divided into 4 ie fixed costs, variable costs, economies of scale and economies of scope. The proportion of larger financing in business operating costs in the amount of $80 \%$ of capital and $20 \%$ for production financing. Found also in UMKM in Rokan Hulu does not have the cost structure due to the lack of expertise in financial reporting.

\section{Revenue Streams}

revenue streamsthe company's revenue earned from customer segments. UMKM in Rokan Hulu generate revenues from sales of products with mekanismi advantage of the sales price that has been added in the desired profit estimates as well as to get an injection of funding from third parties are cooperative (BUMDes) and the Bank. 


\section{SWOT ANALYSIS}

SWOT analysis describes the strengths, weakness, opportunities and threats of MUMKM in Rokan Hulu has strengths in terms of value propositions (reasonably priced, excellent quality, Segment consumers clear, the balance between profit and quality) and key partnerships (relationships with customers, supplier good enough). While the weakness in terms of channel (Some UMKM rely on the consumer to come), revenue streams (only have one source of income), key resources (low employee performance), key partnerships (only have one supplier) and cost structure (large fixed costs). Opportunity owned that business communities are already using social media, community economic wriggling in Rokan Hulu began to rise, majority of UMKM in Rokan Hulu in the stage of building a home.

\begin{tabular}{|c|c|}
\hline Strengths & Weakness \\
\hline Affordable prices & $\begin{array}{l}\text { Some UMKM rely on the consumer to } \\
\text { come }\end{array}$ \\
\hline Good quality & Revenue only comes from one source \\
\hline Relationship with customers, suppliers fairly good & Low employee performance \\
\hline Clear consumer segment & Supplier owned by only one person \\
\hline $\begin{array}{l}\text { Having a strong business and a balanced focus } \\
\text { between profit and quality }\end{array}$ & fixed costs large enough \\
\hline opportunity & Threats \\
\hline $\begin{array}{l}\text { Economic stretching society in Rokan Hulu Start } \\
\text { Rising }\end{array}$ & Customer tastes different \\
\hline $\begin{array}{l}\text { The majority of UMKM in Rokan Hulu in the } \\
\text { stage of building all }\end{array}$ & $\begin{array}{l}\text { Sufficient number of competitors in the } \\
\text { same business world }\end{array}$ \\
\hline $\begin{array}{l}\text { Business communities are already utilizing social } \\
\text { media }\end{array}$ & \\
\hline
\end{tabular}

Source: Primary Data Processing, 2017

\section{BLUEOCEAN AND STRATEGY BY BUSINESS MODEL CANVAS}

\section{Customer Segments}

UMKM in Rokan Hulu segmentsnya customer must develop a more focused and working on the online store segment or increase the use of social media.

\section{Value propositions}

UMKM in Rokan Hulu should improve value propositions available today. UMKM in Rokan Hulu can sell and produce products required by consumers taking into account the trend berkermbang.

\section{Channels}

UMKM in Rokan Hulu should be able to expand the range through its own channels of UMKM in Rokan Hulu can maintain what exists today.

\section{Customer Relationships}

In this element, UMKM in Rokan Hulu can maintain the function of customer relationshipsnya. UMKM in Rokan Hulu category of customer relationships can develop into a self-service (using the online system).

\section{Revenue Streams}

UMKM in Rokan Hulu should be able to raise their income by memanfaatka opportunities that exist for example with the franchise system. As for the moment, pemililk UMKM should be careful in the use of capital because most business owners capital comes from bank loans.

\section{Key Resources}

Key resources which can be developed by UMKM in Rokan Hulu for example, provide training to employees.

\section{Key Activities}

Activities undertaken by UMKM in Rokan Hulu is defining a new customer segments, planning concepts that will develop, implement, and find a suitable strategy in each of its business activities. Such as combining the reseller and distribution activities.

\section{Key Partnerships}

UMKM in Rokan Hulu can add suppliers to be 2 or 3 people. In terms of customers, should UMKM in Rokan Hulu can provide 
specificity to customers who become reseller or wholesale buyer, for example by providing discounts or membership card in order to make the customer feel more exclusive.

\section{Cost Structure}

UMKM in Rokan Hulu need to reduce fixed costs is the cost of store rental and salary costs karyawan.serta there should be reporting on the financial performance of each business, example the balance sheet, income and cash flow.

\section{CONCLUSION}

Based on this research, the writer can bring some conclusions including Business adalahModel MUMKM in Rokan Hulu largely remains relatively still traditional ninth block where the main element of the Business Model Canvas filled with little information. As well as the field found some SME entrepreneurs do not want to provide information about its business, it gives the sense that the UMKM have not been able to compete with other competitors. It should be done on the renewal of SME Business on its business model in all elements. For example, has begun to market segmentation segmentation determination as demographic, psychological, geographically different than before. In this study has limitations that UMKM were interviewed did not fully provide in-depth information.

Methods business model canvaseasier to identify clearly to a strategy that is owned by the company or UMKM. The results showed some weaknesses and strengths of UMKM in Rokan Hulu. Provide advice to authors is that the method of our business model canvas highly recommend to business owners of UMKM in Rokan Hulu for use in performing floating long-term business strategy for the business is growing. Every UMKM must have a vision for business development in the future. Future research may use the samples and the wider region.

\section{BIBLIOGRAPHY}

Boedianto, Laurentia Prisca and Harjati, Dhyah. Business Development Strategy 2015. At the Depot selaris Approach Business Model Canvas. Journal of the University of Petra. Surabaya.

Boone, Louis E. Kurtz, David L. 2008. Introduction to Business Contemporary, book 1. Jakarta: Four Salemba.

Bradford, Robert W. Duncan, Peter J., Tarcy, Brian, Simplified Strategic Planning: A No-Nonsense Guide for Busy People Who Want Results Fast, [Online] Available: http://www.QuickMBA.com/Strategy/SW OTAnalysis [2016 May 2016]

Dewobroto, Vishnu Way. 2013. Use of the Business Model Canvas as a Basis For Creating Alternatives Business Strategy and Feasibility. Journal of Trisakti University. Jakarta.

Dhewanto et al. 2015. Management of Innovation for Small and Micro Enterprises. Alfabeta. Bandung.

Moleong, Lexy J. 2014. Qualitative Research Methods. Youth Rosdakarya. Bandung.

Osterwalder, Alexander and Yves Pigneur. 2012. Business Model Gneration. PT Elex Media Komputindo. Jakarta.

Pearce and Robinson, 2007, Management Strategy, Salemba Four, Jakarta

Daughter, FFT (2015). Business Model Innovation Analysis Approach Using Busines Model Canvas. Journal of Telkom University. Bandung.

Stefan, Slavik and Richard Bednar. 2014. Analysis of Business Models. Journal of Competitiveness. University of Economics in Bratislava.

Sugiyono. 2013. Business Research Methods. Alfabeta. Bandung.

Thompson, (2008), Crafting \& Executing Strategy; The Quest for Competitive advantage, Sixteenth Edition, McGrawHill International Edition. 
Tjitradi, Elizabeth Cindy. 2015. Evaluation and Design of Business is based on the Business Model Business Model. Journal of the University of Petra. Surabaya

Law of the Republic of Indonesia Number 20

Year 2008 on Micro, Small and Medium Enterprises 